\title{
Issues and Alternatives for the Improvement of the Exercise Specialist Qualification System
}

\author{
Deogjo Jung*
}

Seowon University, Cheongju, Korea

\begin{abstract}
Received: October 30, 2017

Accepted: January 20, 2018

Published online: January 31, 2018

PURPOSE The purpose of this study is to discuss several issues that need to be improved and changed in the Exercise Specialist Qualification System focusing on eligibility of the exercise specialist, exams, including written, oral, and practical test, and administration of training courses.

Keywords:

Exercise specialist

Exercise specialist qualification system

Oral and practical test

Training course

MAIN BODY The exercise specialist should have a bachelor's degree related to physical education that includes required courses. However, the new changes are that the number of required courses will be increased and the department certification system in physical education will be developed. The goal for the eligibility into this Exercise Specialist Qualification System will be to only allow only individuals who have physical education degrees or related. It is an alternative plan against the 2015 Exercise Specialist Qualification System, which allowed all individuals who had a bachelor's degree to be candidates regardless of their undergraduate major.

The written test will reduce its subjects from eight to six. Catering to common standards, the subjects "Evaluation of Health and Fitness," "Exercise Prescription," and "Exercise Testing" will be combined; and "Prevention and Care of Athletic Injuries" will become "Exercise Injury."It should be noted that the written test excluded "Sport Psychology" and that "Exercise Nutrition" was included in "Exercise Physiology." Also, "Exercise Training" was included as a new written test subject. It may be difficult to forecast these numbers due to differences in positions held by certified individuals, including ministry of education, exercise specialist, faculty, and students. The exercise specialist certification exam should follow a systematic and standardized manual and evaluation index to enhance the objectivity, validity, and reliability of the certification.

The class hours of the training course were also changed. General training course hours decreased from 120 to 40 , and practical training course hours decreased from 80 to 62 . The reasons for decreasing course hours included: training center were mainly located in the Seoul area and lacked in other areas, inconsistent quality among training centers, and the lack of evaluations regarding the candidates' attitude and class participation during the training courses. Ultimately, improvements to the training courses will allow for the development of multiple curricula.

CONCLUSIONS The Exercise Specialist Qualification System was developed in 2015, but several issues have been identified that include the tasks of the exercise specialist, eligibility as an exercise specialist, qualification examinations, and training courses that need improvement. Increasing the employment of exercise specialists is important in order to develop cooperation among certifying agencies.
\end{abstract}

( ) The Asian Society of Kinesiology and the Korean Academy of Kinesiology

\section{서 론}

2013년 7월 2일 [국민체육진흥법시행령] 일부 개정안 이 국무회의를 통과했다. 이 개정안은 2012년 2월 17일에

*Correspondence: Deogjo Jung, Department of Physical Education, Seowon University, 377-3 Musimseo-ro, Seowon-gu, Cheongju, Korea.

E-mail adress: jdj1116@hanmail.net
2015년 1월 1일 시행하기로 개정되었던 [국민체육진흥법] 이 위임한 사항을 정하기 위한 것이었다. 이 개정안은 (1) 체육지도자의 자격 종류/등급, (2) 체육지도자의 자격취득 을 위한 응시 요건, (3) 자격취득 과정인 자격검정(필기시 험, 실기 및 구술시험)과 연수 과정의 내용, (4) 자격검정이 나 연수 과정의 일부 면제 대상과 면제되는 사항, (5) 자격 검정 기관과 연수 기관의 지정 기준 등을 개편하는 내용 
을 포함하고 있다(Ministry of Culture, Sports and Tourism, 2014).

개정 전까지는 운동처방 분야의 체육지도자 기능을 1 급 생활체육지도자가 수행해왔다. 하지만 시작과정에서 부터 자격명칭의 함축성, 업무범위의 제약성, 자격검정 시험 응시자격의 학력 제한, 자격연수원의 필요성, 취업/ 창업 지원책의 부재 등 여러 가지 측면에서 문제점들을 내포하고 있었다. 그러나어떠한 실질적인 보완책이나개 정 없이 시행되어 오다가(Jung, 2015), 2015년 개편 시행된 자격제도에서 1 급 생활체육지도자는 건강운동관리사로 개편되었다. 이전의 1 급 생활체육지도자와는 달리 건강 운동관리사의 정의 및 업무 범위, 응시자격, 자격검정 방 법, 자격검정 과목, 자격검정 주관 및 시행기관, 실무연수 등 많은 부분에서 새롭게 달라진 부분이 있어 이에 대한 충분한 논의와 문제점에 대한 고찰이 필요했지만, 새롭 게 출범하는 건강운동관리사 또한 준비과정의 소홀과 운 영과정에 대한 문제점들을 보완하지 못한 채 시행되었다 (Jung, 2015).

개편 당시 관련학과의 교수, 현장의 전문가, 기존 1 급 생활체육지도자 기취득자 등에 의해 지적된 문제점들에 대한 보안의 시기를 놓쳐 2-3년 시행하면서 문제점을 보 완 할 수밖에 없다는 결론을 내린바 있다. 자격제도 전반 에 대한 문제점을 비롯해 건강운동관리사의 자격 요건, 필기시험과목 개선, 실기 및 구술시험 운영, 연수 시간 및 운영의 문제점, 건강운동관리사의 취 창업 및 역할 재 정립, 건강운동관리사의 업무범위 확대, 건강운동관리 사 배치 확대 등에 대한 문제가 지속적으로 제기되었다. 특히, 가장 논란의 대상이 되었던 [국민체육진흥법 시행 령]제9조 2 항의 건강운동관리사 업무범위에 언급되었던 “[의료기사 등에 관한 법률시행령] 제 2 조 제 1 항 제 3 호의 신체교정운동 및 재활훈련은 제외한다” 문구에 대해 체 육계의 공분(公憤)과 해결방법 찾기에 많은 의견이 모아 졌지만 뚜렷한 해결방법은 찾지 못하였고 추후 [국민체 육진흥법 시행령] 제9조 2 항의 개정을 통해 근본적으로 해결해야 한다는 것이 중론(衆論)이였다(Korean Institute of Sport Science, 2013). 2015년 체육지도자 자격제도 개편 이후 미비점 분석 및 개선방안 제시를 목적으로 체육지도 자 자격체계 확립을 위한 제도개선 연구가 진행되고 있는 시점에서 도출된 문제점들을 바탕으로 하고자 하였다. 본 연구에서는 2015 년 개편당시 지적되었지만 법적인 절차 와 시간적 여유 등 여러 가지 이유 때문에 개선하지 못한
사항들과 3 년 동안 시행되는 과정에서 새롭게 부각된 건 강운동관리사 제도의 문제점 및 개선되어야 할 점, 더 발 전적인 정착을 위해서 반드시 논의되어 해결되어야 할 점 등을 건강운동관리사 자격제도와 관련된 자격 요건, 필기 시험, 실기 및 구술시험, 연수원 운영과 관련된 문제 중심 으로 살펴보고자 하였다.

\section{본 론}

\section{건강운동관리사 자격 제도 및 자격 요건 개선}

3년 동안 시행되는 과정에서 많은 논란이 되었던 것이 바로 건강운동관리사 응시자격이었다. 과거의 1 급 생활 체육지도자 응시자격의 큰 골격은 (1) 2 급 생활체육지도 자 자격을 가진 자로서 선수 또는 체육에 관한 행정/연구/ 지도 분야의 경력이 3 년 이상인자, (2) 체육 분야 석/박사, (3) 운동처방전공의 박사학위를 취득하고, 운동처방 분야 의 종사기간 또는 연구 및 교육경력이 3 년 이상인 자로서 특별과정을 이수하고 전공과목자격검정을 통과한 자, (4) 운동처방전공의 석사학위를 취득한 자로서 일반과정 이 수 후 자격검정을 통과한 자로 되어 있었다. 한편, 2015년 부터 2차례에 걸쳐 완화된 자격기준의 요지를 살펴보면 (1) [고등교육법]제2조에 따른 학교에서 체육분야에 관한 학문을 전공하고 졸업한 사람(졸업예정자 포함)으로서 체육 분야 전문학사, 학사, 석.박사, (2) 종전 2 급 생활체육 지도자 자격을 가진 사람으로서 해당 자격 종목의 선수 경력이 3 년 이상인 사람과 체육에 관한 행정 - 연구 - 지 도 분야의 경력이 3 년 이상인 사람으로 완화하였다. 더불 어 논란의 대상이 되었던 체육분야 인정범위는 학위(학 과, 전공)명에 체육, 스포츠, 운동, 건강이 포함되면 인정 (복수전공은 인정하고, 부전공은 불인정함)하였다. 시행 첫해 이에 해당되지 않은 학과의 반발로 교과과정에 이들 학과에서 배우는 과목이 포함되어 있으면 모두 인정해주 었으며, 몇몇 대학의 학과에서는 학위명이나 학과 또는 전공을 바꾸는 경우도 있었다(Jung, 2015).

당시 정권의 학력차별 폐지와 직역 간 칸막이 철폐 등 의 정책적 방향의 영향으로 학력 제한이 완화되어 학력 제한과 진입 장벽이 완화되었으며, 이에 대해 많은 학계 전문가들이 전문성 약화에 따른 질적 저하를 우려하였다.

그도 그럴 것이 특별과정이었지만, 해당 전공영역 3년 이상의 박사학위 취득자가 자격검정을 통해 취득할 수 있 었던 자격증을 전문대학만 졸업해도 받을 수 있게 된 것 
이다. 이에 대해 학계에서는 완충 시기나 아무런 대책 없 이 갑작스럽게 학력제한을 완화함에 따른 전문성, 학문성 결여에 대한 우려의 목소리가 매우 커졌으며 현재까지도 이어지고 있다.

더불어 체육관련 분야에 비체육계 분야의 전공자들에 대한 칸막이가 없어 체육관련 분야의 전공자들에 대한 역 차별 논란이 제기되었다. 하지만 건강운동관리사는 '운동 의 계획, 운동지도, 운동감독, 운동평가 등에 관한 복합적 이고 과학적인 운동교육 및 기능 업무를 수행'해야 하기 때문에, 운동에 대한 기본 능력과 지식이 없이는 불가능 하다는 결론이 도출되어 체육 분야 관련 전공자로 대상을 한정하였다(Jung, 2015).

체육지도자 자격체계 확립을 위한 제도개선 연구 (2017)과정에서 논의되고 있는 단기적 개선안을 살펴보 면 현행 자격 요건을 그대로 두고 체육관련 분야의 전공 자들의 역차별을 다소 해소하고 건강운동관리사의 직무 영역을 고려할 때 체육에 대한 이해가 반드시 필요하다 는 전제아래 직무와 법정 이수 과목 중 최소 과목 및 학점 을 제시하고 있다. 법정이수과목의 궁극적인 목표는 건 강운동관리사의 전문성 강화 및 질적 제고를 위한 미국 의 NATA(National Athletic Trainers' Associaion; NATA)의 ATC(Certified Athletic Trainer)와 같이 학과인증제로 발전 시켜 나아가겠다는 취지로 법정이수과목을 점차적으로 늘려 나가겠다는 것이다.

미국 내 Athletic Training 전공 관련의 유일한 자격증 인 ATC 자격증 시험을 보기 위해서 시험응시자들은 CAATE(Commission on Accreditation of Athletic Training Education)에서 전공 인증을 취득한 대학 혹은 대학원 에서 Athletic Training을 전공하여야 한다. CAATE로부 터 Athletic Training 전공인증을 받기 위해서는 대학에서 는 관련 규범에 맞는 아주 까다로운 절차들을 걸쳐야 하 며, 이러한 인증 이후에도 매년 전공프로그램 보고서를 CAATE에 제출하여야 한다. 인증기간이 마무리되는 마지 막 연도에는 인증초기와 같은 서류들을 준비하고 제출 보 고하여야 하며 이러한 절차 다시 통과하여야 전공인증을 유지할 수 있다. ATC시험은 BOC(Board of Certificatoon) 에서 시험출제 및 총괄 주관하며, NATA는 Annual Conference를 주관하며 주 업무는 회원 관리를 도맡아하고 있다.

건강운동관리사 자격제도 개선안에서는 먼저 최소 8 과목 최소 20 학점에서 시작하고 점차 늘려 최소 14 과목 최 소 35 학점까지 확대한 다음 학과인증제를 도입하겠다는
계획이다. 이는 영양사 국가시험자격기준을 벤치마킹 한 것으로 보인다. 영양사 자격시험을 보기위해서는 전문대 학 또는 4년제 식품영양학과에서(또는 관련 유사학과) 영 양관련 18 과목 52 학점을 모두 이수하여야 한다.

2015년 개편당시와 그 이전에도 개정안과 같은 논의가 있었으나각 대학 및 학과의 교과과정 조정, 교수 충원, 기 존 교수들의 수업시수 확보 등 각 대학의 다양한 이해관 계 때문에 받아들여져지지는 않았다. 각 대학이나 학과가 교육부의 특성화 사업과 평가에 억매여 있는 상황에서 그 리고 대학의 이해관계가 얽혀있는 상황에서 이전과 달리 이번 개선안이 받아들여져 시행될 수 있을지는 의문이다. 특히, 미국 NATA의 ATC와 같은 인증제가 도입될 수 있을 지 의문이며, 이러한 합의가 이루어진다고 하여도 정착까 지는 많은 어려움과 과제가 있을 수 있다.

\section{필기시험과 필기시험 과목 조정}

과거의 1 급 생활체육지도자의 필기시험은 과목이 많 아 부담이 크다는 비판이 있어 2015년 제도개편에서는 건 강운동관리사 필기시험과목이 종전 12 과목에서 8 과목으 로 대폭 축소되었다. 당시 필기시험과목이 자연과학분야 로 이루어져서 인문사회과학 분야의 전공과목들이 포함 되지 않는 것에 대해 상반된 이견이 많았지만 이는 건강 운동관리사의 정의나 직무 및 업무 영역에 대한 깊이 있 는 이해가 부족한 것에 기인하였다. 하지만 이에 대한 이 해와 설득으로 다행스럽게도 큰 논란 없이 받아들여진바 있다.

이번 개선안의 내용을 살펴보면, 현행 8과목(기능해부 학, 운동생리학, 스포츠심리학, 건강/체력 평가, 운동처방 론 병태생리학, 운동상해, 운동부하검사)의 시험과목을 6 과목(인체해부학, 운동생리학, 운동처방론, 병태생리학, 운동손상학, 운동트레이닝)으로 축소하고 있다.

이번 필기시험과목 개선안은 자격증을 시행하는 대상 과 질환을 포괄하는 교과목으로 구성하고, 건강운동관리 사의 대상을 크게 일반인과 질환, 운동선수를 나눈 것을 알 수 있다. 또한 건강운동관리사의 직군을 '병/의원', 선 수트레이닝/재활', ‘헬스피트니스'로 구분하고 최근의 요 구는 일반인을 포함한 선수들의 운동으로 인한 그리고 고 령화로 인한 근골격계 질환이 매우 중시되고 있기 때문에 이를 고려한 것으로 보인다.

2015년 개편 당시 가장 걱정스럽고 논란이 되었던 것 이 바로 '건강/체력 평가', '운동처방론', '운동부하검사'시 
험과목이었다. Jung(2015)은 미국스포츠의학회(ACSM)의 운동검사 및 처방 가이드라인(ACSM, 2015)을 보면 3과목 은 1 과목으로 구성되어 있고. 대부분의 관련 전문서적을 살펴보면, 운동처방의 순서에 따라 '건강/체력평가' 영역, ‘운동부하검사’ 영역, ‘운동처방’ 영역이 순차적으로 기술 되어 있다고 하면서 따로 분리해서 학습할 수도 있지만, 이들 영역은 서로 연관되어 있기 때문에 하나의 교과목 이라고 하였다.

또한 '건강/체력 평가'와 ‘운동부하검사'과목은 실습과 관련된 내용이 많고 필기시험과목에 포함하여 하나의 과 목으로 분리하기에는 지식의 총량이 턱없이 적다. 이러한 이유 때문에 이 3 과목은 과목 간 중복 문제 출제, 조잡한 문제 출제의 가능성, 기출문제와 상이한 문제출제의 어 려움, 실기시험과의 중복 가능성이 있다는 지적이 있었 지만, 이미 법령에 과목이 명기되어 있어 법령 개정 전까 지는 시행할 수밖에 없었다. 이러한 지적은 자격제도가 3 년 동안 시행되면서 사실로 들러났다. 다행스럽게도 이번 개정안에서 문제의 심각성을 이해하고 개선하기 위해 이 3 과목을 하나의 과목으로 통합하려고 하고 있다. 다행스 럽고 반드시 개선되어야 할 부분이다.

$\operatorname{Jung}(2015)$ 은 교과목 명칭에 있어서도 ‘운동상해’ 교과 목은 실기 및 구술시험 과목인 운동손상 평가 및 재활과 연관시켜 ‘운동상해’ 보다는 ‘운동손상학' 또는 ‘운동손상' 이라고 수정하는 것이 바람직하다고 하였는데 이번 개정 안에서 ‘운동상해’과목을 ‘운동손상학'으로 명칭을 변경 하고 있다.

2015년 개편 당시 '기능해부학'에 운동역학을 포함시 킨 것에 대해 운동역학을 전공하는 일부 학자들은 부정 적 의견을 제시하기도 했다. 기능해부학에 운동역학을 포함하는 것보다는 '운동학(kinesiology)'으로 교과목 명 을 수정하고 교과내용도 ‘운동학’에 맞추어 변경하는 것 이 이러한 문제를 해결하는 한 가지 방안이 될 수 있다고 생각한다. 운동손상 평가 및 재활 영역에서 운동손상 평 가의 기본 지식과 이론을 이해하기 위해서는 반드시 '운 동학’ 또는 ‘운동기능학’이 필요하다. 운동기능학은 물리 치료 분야와 재활의학 분야에서는 매우 중요한 과목으로 운동의 법칙성이나 원리를 규명하는 학문이다. 체육이 더 발전하기 위해서는 ‘운동학' 또는 ‘운동기능학’이 반드시 교과목으로 채택될 필요가 있다고 생각된다(Jung, 2015).

이번 개선안에서는 교과목 명을 인체해부학으로 변경 하면서 기능해부학적 및 역학적 지식을 포함한다고만 언
급하고 있다. 추후 교과내용이 어떻게 구성될지 모르지 만 변경하는 특별한 이유와 당위성이 부족해 보인다. 건 강운동관리사의 업무 및 직무영역과 ‘운동손상학’ 과목과 의 관련성 및 연관성으로 볼 때, 인체해부학보다는 '기능 해부학' 으로 존치하거나 아니면 ‘운동학`으로 교과목 명 을 바꾸는 것이 더 낮다고 생각된다.

이번 개선안에 아쉬운 점이 있다면, 건강운동관리사 직무와 관련성이 없다는 이유로 스포츠심리학이 필기시 험에서 제외되었다는 것이다. 스포츠심리학은 운동참여 자의 동기유발과 행동변화와 관련된 행동변화 이론 및 모 델, 행동목표의 설정, 행동변화 전략, 고객과의 관계 형성, 스트레스 관리 기술 등의 내용 습득이 필요하고, 스포츠 손상과 심리적 중재를 위한 재활과정에서의 심리적 요인, 심리훈련 기술 등에 대한 이론과 지식이 업무 및 직무영 역과 많은 관계가 있음에도 불구하고 필기시험과목에서 제외된 것에 대해 다소 이해가 가지 않는다. 많은 운동처 방 관련 전공서적과 운동손상학 관련 전공서적을 살펴보 면 위에서 언급한 내용들이 포함되어 있는 것을 알 수 있 다. 추후 공청회 등을 통해 필기시험과목에 계속 포함되 는지 아니면 다른 방법을 통해서라도 앞에서 언급한 내용 들에 대해서는 필기시험에 포함되었으면 하는 바램 이다.

필기시험과목 개선에 있어서 운동트레이닝 및 운동영 양학은 건강운동사의 특성을 나타내는 전문 과목이므로 체력평가 및 컨디셔닝을 운동트레이닝에 통합하여 신설 한다고 언급하면서 ‘운동트레이닝’ 과목 신설을 제안하 고 있다. 구체적인 언급은 없지만 건강운동관리사 직무 와 연관성이 매우 높다는 이유와 함께 트레이닝 주기화 에 대한 지식을 포함한다고 언급하고 있다. 주기화 이론 을 언급한 것으로 보면 '트레이닝방법론' 교과목이라고 생각되지만, 건강운동관리사의 직무영역을 고려했을 때 는 ‘트레이닝방법론' 보다는 피트니스센터나 개인트레이 닝에 필요한 유산소트레이닝, 저항운동, 소도구 운동, 재 활운동과 관련된 다양한 내용이 포함된 교과목이어야 한 다고 생각한다. 아마도 최종 보고서에서는 과목의 성격과 교과내용에 대한 주요항목, 세부항목 및 세세항목을 밝 힐 것으로 생각되지만, 전문가들의 동의를 받을 수 있을 지는 추이를 살펴볼 필요가 있다(Korea Sports Promotion Foundation, 2017).

그밖에 운동생리학의 영역을 넓혀 운동영양학을 포함 한다고 언급하면서 인간을 대상으로 한다는 점에서 관련 법규 과목이 포함되는 것이 가장 이상적이나 현재 체육관 
련 전공학과의 경우, 이러한 교과목이 구성되어 있지 않 아 향후에 추가되어야 한다고 제안하고 있지만 다소 무리 가 있고 일부 의견이라고 생각한다.

응시생들은 운동영양학이 운동생리학 과목의 일부 영 역으로 포함되어 시험에 출제된다는 것은 하나의 과목이 신설된다는 것으로 생각한다. 겉으로는 필기시험과목에 포함되지 않지만, 실제적으로는 필기과목으로 인식한다. 더욱이, 필기시험과목에 포함되지 않기 때문에 교과내용 에 대한 주요항목, 세부항목, 세세항목을 제시하지 않을 것이다. 이 때문에 응시생들은 교과범위와 지식 총량이 어느 정도인지 가늠할 수 없게 되어 시험을 준비하는데 많은 어려움과 혼란이 있을 수 있다. 때문에 개선안에 포 함시키지 않는 것이 바람직하다고 생각한다. 건강운동관 리사와 업무 및 직무관련성이 더 많은 스포츠심리학이 필 기시험과목에서 빠지고 운동영양학이 운동생리학 과목 의 일부영역으로 포함된다면 많은 반항이 있을 것으로 생 각된다.

현재는 8 과목의 필기시험을 치르고 있으며 각 과목당 20 문항 총 160 문항을 출제하고 과목 당 100 점 만점으로 평 가를 하고 있다. 하지만 과목별 지식 총량의 차이를 반영 하지 못했다는 지적이 있었다. 특히, 건강「체력평가, 운동 부하검사의 경우 시험과목의 세분화로 인한 절대적인 지 식 총량이 작아 그 동안 인접과목과의 중복문제, 난이도 조절 어려움, 기출문제와의 중복 등 많은 어려움이 있었 던 것이 사실이다. 이번 개정안에서는 지식 총량을 반영 하여 각 과목의 배점을 20 점 또는 30 점으로 차등을 두고 각 과목당 100 점이 아닌 모든 과목의 총점수의 합인 총점 을 사용할 것을 제안하였다. 이러한 방식은 영양사 국가 시험에서 사용하고 있으며 매우 바람직한 제안이라고 생 각하지만, 현행 자격검정 합격기준인 과목마다 만점의 $40 \%$ 이상 득점하고 전 과목 평균 $60 \%$ 이상 득점자를 합 격으로 하는 합격기준을 수정해야 할 것으로 생각된다.

개선안에서는 현행 절대평가에 의한 자격검정 합격기 준을 상대평가제로 전환하자고 제안하고 있다. '(가칭) 건 강운동관리사수급관리위원회'를 통하여 당해 연도 적정 수요인원을 산출하고, 수요인원의 $110 \%$ 를 필기시험을 통 하여 선발하고 실기 및 구술시험에서 $10 \%$ 를 탈락시키자 는 제안이다. 하지만, 현실적으로 다소 어려운 점이 많이 있을 것으로 생각된다. '(가칭) 건강운동관리사수급관리 위원회' 구성에 따른 행정적 절차와 운영에 대한 규정을 마련해야하고 당해 연도 적정 수요인원을 산출하는 합당
한 근거를 찾기가 어렵고 위원회 구성과 운영에 관련된 행정적, 법적 준비가 원만하게 이행될지 의문스럽다.

\section{실기 및 구술시험}

현행 실시되고 있는 실기 및 구술시험과목은 총 4 과목 으로 그중 '심폐소생술(CPR)/응급처치'는 자격증 소지자 에 한하여 실시하고 있으며, 그 밖의 과목은 각각 만점의 $70 \%$ 이상을 득점했을 때 합격하는 것으로 되어 있다.

필기시험과 실기 및 구술시험은 상호 보완적이고 연계 성을 높이는 방향으로 출제되어야 한다. 또한 직무 현장 에서 가장 많이 사용되고 직무를 수행하는데 반드시 필 요한 실기 능력을 평가해야 한다. 이를 위해 자격제도 개 선안에서는 나머지 3 과목에 대한 과목 폐지나 과목의 신 설은 하지 않고 부분적으로 과목명을 수정하여 필기 시험 과 실기 및 구술시험의 성격을 명확히 하려하고 있다. 그 동안에는 필기시험과 실기 및 구술시험의 경계가 모호한 문제와 중복되는 시험 문제의 출제가 많았고, 기자재 준 비의 어려움과 심사위원의 선정 및 전문성의 차이 극복, 짧은 출제기간, 너무 많은 응시자 등의 문제로 현장 구현 성이 높은 문제를 출제하는데 어려움이 많았던 것이 사실 이다. 특히, 고가이거나 대형장비가 필요로 하는 실기 및 구술시험 문제를 출제하는데 많은 제한이 있었는데, 이는 실기 및 구술시험장에 고가이거나 대형장비를 배치 활용 하는데 경제적, 공간적 어려움이 많았기 때문이다. 이러 한 문제가 제기되어 필기시험을 통해 수요인원의 $110 \%$ 만 을 상대 평가제를 통하여 선발하자고 제안하고 있다. 하 지만 이는 자격검정을 운영자 중심적 운영에 초점을 맞 춘 결과로써 좋은 방안은 아니라고 생각된다. 대신, NATA 의 $\mathrm{ATC}$ 자격검정처럼 소형태블릿 $\mathrm{PC}$ 를 이용한 동영상 시 험문제나 필답형실기고사 등의 방법을 통해 얼마든지 개 선할 수 있을 것이라고 생각한다. 실기 및 구술시험 응시 자가 많을 때, 동일한 시험 문제를 사용하여 2일간 시험 을 치르거나 오전과 오후로 나누어서 치를 경우, 문제 유 출 등으로 나중에 시험을 보는 응시자가 더 유리할 수 있 고, 시기에 따라 각기 다른 시험 문제를 사용할 경우 난이 도 차이에 따른 공정성의 문제가 제기 될 수 있기 때문에 시험장소와 심사위원을 많이 확보하여 동시 진행하는 것 이 공정성을 높이고 민원을 줄일 수 있는 방법이다. 하지 만 심사위원 확보, 장소확보, 시험 기자재 확보 등 행정적, 경제적으로 많은 비용과 시간이 소요된다. 이러한 문제점 을 해결하고자 이번 제도 개선안에서는 대한운동사협회 
의 운동사 자격시험 실기범위 공개와 같이 실기 및 구술 과목 시험 문제를 사전에 공지하여 응시자들이 현장에서 필요한 실기 기술을 충분히 연습하고 습득할 수 있는 기 회를 유도하고 하고 있지만, 이러한 방법 또한 응시 시점 에 따른 유불리(有不利)를 완전히 해결하기는 어렵다. 민 간자격의 경우 큰문제가 안될 수 있지만, 국가공인시험에 서 시험범위 또는 시험의 내용을 미리 알려주고 자격시험 을 치르는 경우는 보기 힘들기 때문이다.

이러한 문제점은 궁극적으로 체육지도자 검정에 대한 권위 실추와 국가공인 체육지도자의 전문성에 대한 불신 을 야기 시킬 수 있다는 것이다.

그 동안 지적되어 왔던 실기시험에 대한 체계적인 표 준화와 매뉴얼 작업, 평가지표 개발이 이루어져 정확하 고 타당성 있는 평가가 이루어져야 할 것으로 생각된다. 또한 건강운동관리사의 직무 영역과 특성을 정확하게 평 가하기 위한 객관적인 평가 지표가 마련되어야 한다. 실 기 및 구술시험의 경우 표준화되고 체계화된 매뉴얼이 없 다면 시험 전체에 대한 공정성 시비가 일어날 가능성이 크다. 객관성과 타당성을 확보하지 못한 실기 및 구술시 험을 통해 배출된 건강운동관리사는 국민의 생명과 건강 을 심각하게 위협할 수 있고 공정성 시비에서 벗어날 수 가 없다. 따라서 건강운동관리사의 실기 및 구술검정은 다른 스포츠지도사의 검정보다 더욱 철저하게 시행될 필 요가 있다(Jung, 2015).

건강운동관리사의 합격 기준이 필기시험의 경우 8 개 과목 $40 \%$ 이상 득점, 전과목 평균 $60 \%$ 이상 득점이 합격 기준이다. Jung(2015)은 전과목 평균 $60 \%$ 이상 득점보다 각 과목의 $40 \%$ 이상 득점 기준에 문제제기를 한 바 있다. 각 과목의 지식 총량이 각기 다르고 각 과목의 난이도에 따라 다소 어렵게 출제될 수 있기 때문이다. 이러한 경우 $40 \%$ 이상 득점에 실패하면 다른 과목의 성적이 아무리 좋 아도 자격시험에 불합격하는 경우가 발생할 수 있으며, 이 한 과목 때문에 전체 시험은 불합격처리가 되는 경우 가 생길 수 있기 때문에 각 과목의 난이도를 조절하는 것 이 매우 중요하다고 하였다. 실제로 2017년 건강운동관리 사 필기시험 과목 중 어떤 과목에서 $40 \%$ 이하 득점 과락 이 매우 많아 합격률을 좌지우지하는 결과가 나타나기도 하였다.

반대로 영양사 국가시험에서 시행하고 있는 지식 총량 을 반영한 각 과목당 배점을 모두 합한 총점수의 총점을 사용한 다면, 어려운 과목은 포기하고 나머지 과목에서
좋은 점수를 받으려는 현상이 나타날 수 있다. 결과적으 로 합격기준과 합격산출방법에 따른 장단점이 있기 때문 에 다른 자격분야의 합격기준과 합격산출방법을 잘 살펴 본 후 현명한 결정이 이루어졌으면 한다.

\section{연수원 운영}

현행 자격제도에서는 필기시험 합격 후 실기 및 구술 시험을 합격하면 연수과정에 대한 별다른 평가 없이 적정 연수 이수시간만 채우면 최종합격할 수 있었다. 때문에 연수생들은 연수에 대한 집중도나 참여율이 매우 낮았다. 연수를 통한 자질함양이나 직무와 관련된 역량을 키우기 보다는 연수시간을 채우는 데만 관심이 있었기 때문이다. 그러다보니 수업의 태도는 불량하고 형편없었다.

체육지도자 연수원 지정과 운영에 대한 법적인 근거는 [국민체육진흥법 시행령] 제 8 조(체육지도자의 양성과 자 질향상)에서 (1) 문화체육관광부장관은 제 11 조 제 1 항에 따라 국민체육 진흥을 위한 체육지도자의 양성과 자질 향 상을 위하여 국내외 교육기관이나 단체에의 위탁교육, 체 육지도자의 해외 파견과 국외 체육지도자의 국내 초빙강 습, 국외 체육계의 조사와 연구, 체육지도자의 양성을 위 한 연수, 체육지도자에 대한 기술과 정보의 지원, 그 밖에 체육지도자의 양성과 자질 향상을 위하여 필요한 시책을 호(號)로 마련하도록 되어 있다(National Law Information Center, 2017).

Jung(2015)은 건강운동관리사 연수의 목적을 [건강운 동관리사로서 직무상 필요한 일반적인 업무수행 능력을 기르고 기본적인 소양을 함양하는 활동과 전문성을 높이 기 위한 활동을 효과적으로 수행할 수 있는 기술과 능력 을 배양시키는 것을 목적으로 한다] 라고 정의하면서 공 무원의 경우 연수라는 용어 대신 교육훈련이란 용어를 사 용하며 공무원교육훈련법 제1조에[교육훈련을 통하여 국가공무원에 게 국민전체의 봉사자로서 갖추어야 할 정 신적 자세와 맡은 바 직무를 효과적으로 수행할 수 있는 기술과 능력을 배양시킴을 목적으로 한다]고 규정하면서 교육훈련이 직무수행 능력의 향상을 추구하는 것이라고 밝히고 있다.

앞으로 건강운동관리사의 연수는 공무원들이 받는 공 무원교육훈련법 제 1 조와 같이 “건강운동관리사가 건강 지킴이로서 갖추어야 할 인성과 맡은 바 직무를 효과적으 로 수행할 수 있는 역량을 배양시키는” 교육훈련의 성격 을 갖거나 초/중등 신규임용 예정교원 직무연수와 같은 
성격의 연수가 필요하다.

교사들의 경우 다양한 연수를 통해 교사로서 갖추어야 할 역량을 높이고 있다. 의사나 간호사 등과 같이 보수교 육을 통한 역량강화가 아닌 연수를 통한 역량을 강화를 실시하고 있어 교사들의 연수는 보수교육 차원의 연수라 고 할 수 있다.

현재 실시되고 있는 건강운동관리사 연수는 대학에서 배우고 와야 될 직무역량 강화를 위한 실기 및 실습교육 을 연수를 통해 하고자하는 것이다. 이러한 연수를 200시 간이나 하는 것은 도저히 이해가 되지 않는다. 현재의 건 강운동관리사 연수프로그램에 포함된 것들은 이미 대학 에서 배우고 익혀서 필기시험과 실기 및 구술시험을 통해 검증받아야 할 내용들이다. 이러한 관계는 대학의 이론 과목과 실험 및 실습과목을 충실하게 이해해야 한다는 근 거를 제공하는 것으로 결국은 대학의 교과과정과 교수의 질을 건강하게 만들게 하는 동기가 된다. 이러한 역할 분 담을 통해 대학은 건강운동관리사에 맞는 교과과정을 운 영하고 전공 이론 수업뿐만 아니라 충분한 실기 및 실습 수업을 통해 직무역량을 강화해야 한다. 아울러 실기 및 실습수업을 위한 충분한 실습 환경을 마련하기 위해 실 기 및 실습 기자재 확보, 우수한 강사진 구성 등 건강운동 관리사 합격을 위한 노력과 타 대학과의 경 쟁력을 갖추기 위해 많은 노력을 기울이게 될 것이다.

이러한 이유로 현행과 같은 건강운동관리사의 연수는 폐지하거나 그 목적과 방향 그리고 내용을 과감하게 재수 정해야 할 것으로 보인다.

2015년 개정되기 전 체육지도자 자격제도에서는 연수 는 필기시험을 준비하는 과정으로 변질되어 시행되었지 만, 2015년 이후 자격제도에서의 연수는 이론적 지식보다 는 실무연수에 초점이 맞추어져 있다(Jung, 2015). 2015년 이후 과감하게 필기시험 준비를 위한 연수 내용을 대학으 로 돌려보냄으로써 대학의 교과과정을 알차게 꾸미는데 기여했고 학문적 성장도 가져왔다. 더 나아가 [국민체육 진흥법 시행령] 체육지도자의 연수과정(제 11 조 관련)의 건강운동관리사 연수 내용 중 건강/체력 측정평가 및 운 동부하검사 실무, 건강 및 체력 증진 프로그램 계획 수립/ 운영, 주요 질환 및 만성퇴행성질환에 대한 운동처방 및 프로그램 운영, 운동손상 관리 및 지역사회 건강운동, 현 장실습은 대학의 교과과정 내에서 운영하고 선수「지도 자/심판윤리/선수와 인원, (성)폭력 방지, 차별 방지, 공정 경쟁, 반도핑과 같은 스포츠윤리, 그 밖에 문화체육관광
부장관이 필요하다고 인정하여 고시하는 사항에 대해서 만 연수과정에 포함되어야 한다.

연수생들의 서울(연세대)지역으로의 쏠림 현상 또한 매우 심각한 문제점으로 드러나고 있다. 이 또한 예상했 던 바였는데 3 년 동안 운영을 통해 드러난 문제점은 예상 보다 더 많은 문제점을 드러냈다. 2015년 연세 대 152명, 순 천향대 41명, 계명 대 39명 조선대 연수운영 포기, 2016년 연세대 179 명, 순천향대 53명, 계명 대 41 명, 조선대 16 명, 2017년 연세대 155명, 계명대 45명, 순천향대와 조선대는 연수운영을 포기하였다. 이러한 이유는 건강운동관리사 합격생의 생활환경이 대부분이 수도권 중심이며, 그들의 일자리도 수도권에 있다는 것을 암시하고 있다. 이러한 현상은 연수생이 집중되는 서울(연세대)지역의 경우 교 육환경 준비, 실습기자재 확보, 우수한 강사진 확보, 입시 시기와 중첩으로 인한 강의실 확보 어려움, 실습기관 섭 외 및 확보 어려움 등 많은 문제점이 드러났다. 결국, 이 러한 문제점들로 인해 연수를 통해 얻으려했던 건강운동 관리사의 직무역량 강화는 요원(遼遠)할 수밖에 없었다. Jung(2015)은 연수생 쏠림현상의 해결할 수 있는 방법으 로 연수기관 대학의 특성화대학 선정과 지원방법을 제시 하기도 했으며, 연수원에 따라 일반연수와 현장실습을 특 성화하여 발전시키는 방안, 인접한 연수기관이 연계하여 교육을 분담하는 방안 등을 제시한바 있다.

이번 제도 개선안에서는 일반연수시간을 대폭 축소하 고 현장실습기관별 실습시간을 축소와 함께 조절하겠다 고 제시하고 있다. 더불어 수도권에 제 2 , 제 3 의 연수원을 추가로 설치하는 방안도 제시하고 있다. 반대로 연수생 이 부족한 지방연수원기관의 재정문제를 해결하고 서울 로 집중되는 현상을 막기 위해 중앙관리시스템으로 전환 하려는 움직임을 보이고 있지만, 구체적이고 실효성 있는 세부방안은 제시하지 못하고 있다. 실제로 현재 연수기관 에서 실시하고 있는 연수내용이나 지침은 중앙에서 관리 하고 있기 때문에 현재에도 교과과정이나 연수 대한 모든 운영은 중앙에서 관리하고 있다. 때문에 이를 해결하기 위해서 문화체육관광부와 체육진흥공단의 새로운 정책 적 판단이 있어야 할 것으로 보인다.

현행과 같은 연수가 계속해서 시행된다면, 각 지역 간 에 발생할 수 있는 연수강의의 질 관리나 평준화를 위해 서 연수교재의 집필이 고려되어야 한다. 연수교재를 공통 으로 사용함으로써 일반연수와 현장실습의 내용 중복을 피할 수 있고 지역 간 연수원의 강의 내용 및 질 차이를 해 
소할 수 있기 때문이다(Jung, 2015).

이번 제도 개선안중 실효성 있는 제안은 현장실습기관 확대를 위해 국민체력100 체력인증센터(전국에 39개 센 터)와 지역스포츠과학센터(전국에 8개 센터, 매년 1 2개 소 신설 계획)를 이용하여 현장실습 기관으로 활용하겠 다는 것이다. 매우 현실성 있는 제안이라고 생각된다. 왜 냐하면, 이 두 곳의 사업을 관리하는 주체가 같고 문화체 육관광부에서 통제가 가능하기 때문에 몇 가지 장애요인 만 제거된다면 충분히 실행가능하다고 생각된다.

현장실습시간 재조정과 함께 현장실습기관을 피트니 스센터(30시간), 보건소(30시간), 병원(30시간)으로 나누 고 이중 2곳의 현장실습기관을 선택하도록 하였다. 실제 로 연수생이 1년 이상 피트니스센터, 보건소, 병원의 한 곳에서 근무하고 있다면 현재 근무지에 대한 현장실습을 면제해주겠다는 것이다. 이러한 방법을 통해 연수시간을 줄여주고 중복현장실습을 피하고, 연수실습기관의 확보 와 운영을 위한 틈을 주겠다는 것이다. 하지만, 현장실습 을 어떻게 하고 어떻게 관리하고 어떻게 평가하겠다는 세 부적인 제안은 아직까지 제시하지 못하고 있다.

현장실습이 정상적으로 운영되기 위해서는 현장실습 에 대한 표준화되고 체계적인 운영지침이 마련되어야 한 다. 더불어 현장실습이 지금과 같이 파행적으로 운영되지 않고 건강운동관리사가 갖추어야 할 직무 소양과 인성 함 양, 현장실습 위주의 실무연수를 수행할 수 있는 역량을 키우기 위한 현장실습의 목적을 달성하기 위해서는 현장 실습 방법, 현장실습 평가에 대한 세부적이고 구체적인 지침마련이 반드시 필요하다.

연수의 필요성과 목적에 대해서는 모두가 공감하고 있 지만, 실제로 운영하는 데는 생각지도 못한 많은 일과 노 력, 유관기관의 협력이 필요하다. 하지만 이러한 문제점 들을 연수기관이 스스로 해결해야한다는 것은 쉽지 않고 불가능하다. 때문에 현행과 같은 연수는 점차적으로 폐지 하는 것이 바람직하다고 생각한다.

국내의 건강운동관리사와 직무영역이 비슷한 국외 의 ACSM(American College of Sports Medicine; ACSM), NATA(National Athletic Trainers' Association; NATA), NASM(National Academy of Sports Medicine; NASM) 등 어 느 외국자격제도에서도 필기시험, 실기 및 구술시험을 합 격한 후 연수를 따로 실시하는 단체는 존재하지 않는다. 연수의 내용은 과감하게 대학의 교과과정으로 넘기고 연 수대신 보수교육을 통한 전문성 강화와 직무수행 역량을
강화하는 것이 바람직하다.

\section{결 론 및 제언}

건강운동관리사 자격제도가 시행된 지 3년이 지난 지 금도 건강운동관리사의 정의, 업무 및 직무영역, 응시자 격, 자격검정방법, 연수 등에 대한 관심과 우려의 목소리 가 높다. 이러한 문제점을 들을 해소하기 위해서 체육지 도자 자격체계 확립을 위한 자격제도 개선이 진행되고 있 다.

건강운동관리사 자격제도와 관련된 가장 큰 쟁점은 자 격 요건을 전문학사와 체육관련 전공 등 기본 자격을 현 행 대로 유지하되 법정과목 이수자로 제한하는 것이다. 단 기적으로는 법정과목 이수자로 변경한 후 단계적으로 법 정이수과목을 늘려나가고 최종적으로는 사범대학의 체 육교육학과와 같이 '학과인증제'를 도입하여 관련학과 졸 업 생으로 제한하려고 하고 있다. 2015년 개편당시 자격기 준 완화에 따른 전문성 부족에 대한 우려와 체육분야 인 정 및 비관련 학과의 자격 충족에 대한 문제를 해결할 수 있는 좋은 대안이다. 하지만, 이해관계가 얽혀있는 각 대 학의 입장이 다르기 때문에 많은 대학의 동의를 받아낼 수 있을지 의문이다. 전문성과 학문성, 사회적「경제적 지 위가 확보되는 건강운동관리사로 거듭나기 위해서라도 현명한 판단이 있었으면 한다.

필기시험과목에 있어서의 변화는 과목 8과목에서 6 과 목으로 축소된 것이다. 특히, 2015년 개편당시부터 논란 이 되었던 '건강/체력 평가', '운동처방론' '운동부하검사' 과목의 통합과 '운동상해'과목의 명칭을 '운동손상학'으 로 변경한 것은 매우 적절한 판단이며 결정이라고 생각한 다. 다만, 스포츠심리학이 필기시험과목에서 제외된 것, 운동영양학의 내용이 운동생리학에 포함된 것, 그리고 운 동트레이닝이란 과목이 새롭게 채택된 것에 대한 명확한 판단근거가 미약하고 체육계의 동의를 받아낼 수 있는지 에 의문이다. 또한 필기시험과목을 통해 수요예측 인원의 $110 \%$ 를 선발하고 실기 및 구술시험을 통해 최종 $100 \%$ 를 선발하려는 개선안도 수요예측 인원의 근거가 미약하고 정부 주관부처인 문화체육관광부의 입장, 기합격자들의 입장, 응시생들의 입장과 체육계(대학)의 입장이 각기 다 르기 때문에 적절한 합의점을 찾기가 힘들 것으로 생각된 다. 현행과 다르게 제시한 과목별 배점 개선안과 합격기 준 산출방법 등은 체육계의 동의를 받아내는데 큰 문제가 
없을 것으로 판단된다.

건강운동관리사의 위상을 확립하고 평가의 객관성, 타 당성과 신뢰성을 확보하기 위한 실기 및 구술시험에 대한 체계적인 표준화와 매뉴얼 작업 그리고 가장 중요할 것으 로 생각되는 평가지표 개발이 시급히 이루어져야 할 것으 로 생각된다.

현행 연수과정은 일반수업과정 120 시간, 현장실습과 정 80 시간으로 구성되어 적지않은 문제점을 노출하였다. 이번 개선안에서는 이러한 문제점을 잘 직시하고 일반수 업과정 40 시간, 현장실습 62 시간으로 축소하였다.

연수과정에 대한 평가가 없어 이로 인해 수업태도 불 량과 수업의 참여도와 집중도가 매우 낮았다. 그밖에 서 울지역으로의 연수생 집중현상, 현장실습기관의 확보 및 연수생 배치 문제, 연수원간의 강의 질 관리나 평준화와 교재집필의 필요성 등 많은 문제점을 드러내고 있다. 국 내와 국외의 자격제도에 있어서의 연수과정을 살펴볼 때 궁긍적으로 연수과정을 폐지하고 그 대안으로 복수교육 을 강화하는 방향으로 제도가 개선될 필요가 있다.

추후 보수교육에 대한 구체적이 방안, 취업과 창업에 대한 실질적 방안, 건강운동관리사의 정의와 업무범위 확 대, 보건복지부와 문화체육관광부의 부처 간 협력을 통한 취업 및 고용 확대 등에 관한 구체적이고 실질적인 대안 이 마련될 필요가 있다.

\section{Conflicts of Interest}

The authors declare no conflict of interest.

\section{References}

ACSM (2015). The gudieline of Exercise test and prescription 9th edition. Lippincott Williams \& Wilins.

ACSM (2017). Retrieved January 52017 from http://www.acsm.org/

Jung, D. J. (2015). Suggestions for settlement of the certification system for sports/exercise specialist. Kinesiology, 2015, 17(1), $81-92$.

Korean Institute of Sport Science (2013). The reform plan for physical education leader qualifications: Research results from a public hearing held

Korea Sports Promotion Foundation (2017). System improvement committee sourcebook for establishing qualification system of physical education leader

Korea Sports Promotion Foundation (2017). Retrieved January 5 2017 from http://www.kspo.or.kr/

NASM (2017). Retrieved January 52017 from https:/www.nasm. org/

NATA (2017). Retrieved January 52017 from http://www.kspo.or.kr/ Ministry of Culture, Sports and Tourism (2014). National Sports Promotion Law. National Laws Information Center. http://www. law.go.kr 